\title{
Empirical Study on the Influence of Cultural Distance and Board Capital on the Performance of Foreign Direct Investment of Beijing's Cultural and Creative Enterprises
}

\author{
Gang Fang ${ }^{1, a}$, Shan Wang ${ }^{2, b}$ \\ ${ }^{1}$ Business School Beijing Institute of Fashion Technology Beijing, China \\ ${ }^{2}$ Business School Beijing Institute of Fashion Technology Beijing, China
}

\begin{abstract}
Based on the background that China enterprises are becoming more and more active in capital operation in the international scope, this paper selects 14 cultural and creative enterprises in Beijing as the research objects, and analyzes the relationship between cultural distance, geographical distance, capital elements of the board of directors and enterprises' FDI performance. This paper crawled data from the stock exchange and other websites, and further used SPSS data processing software to model and analyze the data obtained, and obtained the empirical research results as follows. The empirical results showed that cultural distance and geographical distance were significantly negatively correlated with FDI performance, which was consistent with the original research hypothesis of the paper. And among the capital factors of the board of directors, the gender diversity, education level, scale and internationalization degree of the board are significantly positively correlated with FDI performance. Finally, the corresponding conclusions and Suggestions are put forward according to the empirical analysis results.
\end{abstract}

\section{Introduction}

Cultural and creative industry is a new industrial form, which takes innovative ideas, advanced technology and intensive intellectual elements as the core to create wealth and provide extensive employment opportunities for the society. Cultural and creative industries play an important strategic role in promoting scientific and technological progress, independent innovation and realizing the transformation of economic growth mode. The steady development of cultural and creative industries is conducive to the construction of a cultural power, the promotion of national cultural soft power and the maintenance of national cultural security.

At present, the scale of Beijing's cultural and creative industries ranks first in China, and cultural and creative industries have become a new bright spot in Beijing's economic development. Specifically, Beijing's core cultural service trade is mainly concentrated in animation and game exports, book copyright exports and film and television exports. And it maintains a good momentum of development, which makes the market of cultural products and services continue to expand. Up to now, the export of cultural products and services in Beijing has spread to more than 140 countries and regions in the world, among which Oceania, Latin America, the Middle East and APEC countries are the main export markets of Beijing's cultural products and services, accounting for more than $50 \%$ of the export volume.

\section{Research Questions}

Foreign Direct Investment (hereinafter referred to as FDI) is not only the inevitable result of the internationalization of enterprises, but also the advanced stage of enterprises' internationalization. In 2018, China's foreign direct investment flow ranked the second in the world, second only to Japan; the investment stock ranked third in the world, after the United States and the Netherlands, and China's foreign direct investment has ranked among the first echelons in the world. Therefore, FDI is also the inevitable trend of the internationalization of Beijing's cultural and creative enterprises and an active choice to enter the global industrial value chain. Many Beijing's cultural and creative enterprises set up subsidiaries overseas to make green-field investment. Meanwhile, cross-border mergers and acquisitions (hereinafter referred to as M \& A) has also become an important form of FDI for cultural and creative enterprises in Beijing.

Enterprise FDI is a resource allocation action across cultural, institutional and geographical boundaries, and it has a high risk of failure. Compared with other traditional enterprises, China's cultural and creative enterprises started late, and the process of "going global" is shorter. Therefore, in the process of FDI, Beijing's cultural and creative enterprises have not been smooth sailing. Some enterprises have encountered difficulties in varying degrees and even suffered failure. The FDI of cultural and creative enterprises in Beijing is not only affected by

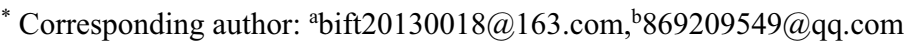


the established cultural distance, but also driven by the structure of the board of directors, as well as the knowledge and experience of directors (Lai et al., 2012). Essentially, the FDI results of Beijing's cultural and creative enterprises are closely related to cultural distance and board capital. Then, in the deep discussion, " how does cultural distance and board capital affect the performance of Beijing's cultural and creative enterprises' FDI? " has become a key issue.

\section{Hypothesis development}

\subsection{Distance and FDI Performance}

\subsubsection{Cultural Distance and FDI Performance}

Culture reflects the basic values of a nation, such as the judgment and measurement of right and wrong, good and evil, beauty and ugliness. 1 Culture not only influences individual beliefs, ideas and behaviors 23 , but also has an impact on company characteristics, such as conflict management, decision-making, leadership, etc. Luostarine (1980) first proposed that cultural distance not only creates knowledge demand, but also hinders knowledge flow among countries. 5 At the same time, through the questionnaire survey of IBM employees, Hofstede (1980) summed up four dimensions of cultural differences between countries. With the deepening of the research, the cultural dimensions gradually expanded to six dimensions.6 Cultural distance was gradually applied to the field of trade, and its inhibitory effect on trade has been the focus of attention of scholars at home and abroad. Through literature review, Didier \& Head (2008) examined 1467 distance effects in 103 papers. The research shows that the negative impact of cultural distance on trade began to rise in the middle of this century, and then maintained a high impact. Although scholars have adopted different research methods, joined the new controlling factors in the model, but the restriction effects of cultural distance for trade is still there. Therefore, this paper puts forward the following assumption for FDI of cultural and creative enterprises in Beijing:

H1: Cultural distance is negatively related to FDI performance

\subsubsection{Geographical Distance and FDI Performance}

Distance is a factor that can not be ignored in bilateral communication. Grossman (1998) demonstrated the relationship between geographical distance and trade cost from the perspective of transportation cost and information cost. The research shows that with the increase of geographical distance, the trade cost also increases. The empirical analysis of Qi Jianhong and Yang Li (2012) shows that China's FDI has obvious regional characteristics, and geographical distance and cultural distance have negative effects on China's FDI. The empirical study of Zhang Xinyi (2016) shows that geographical distance has a significant inhibitory effect on the duration of export trade of cultural products. Therefore, in view of Beijing's cultural and creative enterprises, the following hypothesis is proposed:

$\mathrm{H} 2$ : Geographical distance is negatively related to FDI performance

\subsection{Board Capital and FDI Performance}

\subsubsection{Board Human Capital and FDI Performance}

The director's human capital is the sum of experience and skills brought by individual directors to the decision-making of the board of directors, which involves the natural human capital and professional human capital of directors. Natural human capital includes age, gender and other natural characteristics, professional human capital includes education level, occupation and other professional features.

With the increase of age, directors' working, social and life experience will become richer, which will affect directors' cognition and values. Golden \& Zajac (2001) found that the proportion of directors over 50 years old in the board of directors is positively correlated with the strategic change of enterprises, which indicates that the senior directors have rich and valuable experience in strategic decision-making and have the steady and mature quality of not afraid in face of danger. For the FDI of cultural and creative enterprises, the directors should have the capability and experience to understand different cultures. Therefore, this paper puts forward the following assumption for Beijing's cultural and creative enterprises:

$\mathrm{H} 3 \mathrm{a}$ : Board age is positively related with FDI performance

Gender diversity affects the cognition, behavior and decision-making of board of directors, and then affects organizational consequences such as corporate performance. Women's participation in corporate board of directors can improve the gender structure. They use their own professional experience, thinking mode and emotional preference to provide a new vision for the strategic decision-making of the board of directors. At the same time, gender diversity will affect the decision-making atmosphere of the board of directors and reduce the conflict of the board of directors. Gender diverse boards prefer to adopt strategic control to supervise senior management (Nielsen \& Huse, 2010). For the FDI of cultural and creative enterprises, female directors can generally enhance their understanding of different cultural environments and alleviate the conflicts caused by cultural differences. Therefore, in view of Beijing's cultural and creative enterprises, the following assumption is proposed:

$\mathrm{H} 3 \mathrm{~b}$ : Board gender diversity is positively related to FDI performance

Some researchers believe that education level and reputation of educational institutions are important factors affecting directors' cognition and participation in corporate strategic decision-making. Wincent et al. (2010) confirmed that the number of university degrees owned by the board has a positive impact on the innovation 
performance of enterprises, and the educational background of directors is helpful to enhance enterprise value (Kim \& Lim, 2010). It is helpful to understand the depth of the cultural differences of FDI and help to solve the problem of cultural differences. Therefore, in view of Beijing's cultural and creative enterprises, the following hypothesis is proposed:

$\mathrm{H} 3 \mathrm{c}$ : Board education level is positively related to FDI performance

In the cultural context, the researchers suggest that the diversity of culture and customs will affect directors' cognition and decision-making. The influence of board cultural diversity on board decision-making is supported by some empirical evidence. The ethnic and cultural diversity of the board has a positive impact on cross-border M \& A (Staples, 2008). In particular, the different knowledge, experience and international vision brought by foreign directors will promote the global development of enterprises and help to enhance the value of enterprises (Oxelhim \& Randoy, 2003). According to Perlmutter \& Heenan (1974), the knowledge and experience of foreign directors on special markets and regions can deeply understand the external institutional and cultural environment. Only by establishing cultural communication channels in the host country environment can enterprises better obtain the local dominant position. For the FDI of cultural and creative enterprises, enterprises need directors who have a deep understanding of the external culture. Thus, in view of Beijing's cultural and creative enterprises, the following assumption is put forward:

H3d: The width of directors' cultural background is positively related to FDI performance

\subsubsection{Board Social Capital and FDI Performance}

The director's social capital is the internal and external interpersonal relationships of directors and the potential resources brought about by these interpersonal relationships. Social capital reflects directors' interpersonal networks through which resources and information flow and spread.

The uncertainty of strategic environment and the fuzziness of information make the board have to possess the ability of information processing. The information processing ability of an effective board should be able to deal with the uncertainty it faces, that is to achieve "information processing matching". Pearce \& Zahra (1992) believed that when the company decided to expand its overseas market, it first needed more board members to obtain the necessary experience and background to successfully pursue new market opportunities. For the FDI of cultural and creative enterprises, the strategic decision-making needs more professional knowledge, and the decision-making task becomes more complex. Therefore, in view of Beijing's cultural and creative enterprises, the following assumption is put forward:

H4a: Board size is positively related to FDI performance

The board of directors is a bridge between the company and the external environment. It is a mechanism to manage external variables and reduce environmental uncertainty. The specific behavior of directors depends on their strategic vision and their experience in other enterprises. The network relationship of chain may also be the channel of enterprise innovation knowledge dissemination, which promotes enterprises to adopt new organizational structure (Palmer et al., 1993), and provides support for the selection of $\mathrm{M} \& \mathrm{~A}$ objects and the implementation of $\mathrm{M} \& \mathrm{~A}$ strategies (Haunscild, 1994). For the FDI of cultural and creative enterprises, the board can use the external chain relationship to correctly predict the risks, select competent managers, and formulate feasible investment and management strategies. Hence, in view of Beijing's cultural and creative enterprises, the following assumption is put forward:

H4b: Board interlocking is positively related to FDI performance

Political connections can help enterprises obtain key resources and deal with various business uncertainties. Political strategy is an important determinant of corporate profitability. And the experience of politics and lawyers can help enterprises increase the knowledge of government procedures and the ability to predict government behavior. In particular, enterprises with more industry regulation tend to choose politicians to reduce the cost of industry regulation, and the enterprises with more political affiliated directors have better financial performance (Hillman, 2005). For the FDI of cultural and creative enterprises, the political connection of the board can provide more resources guarantee and investment clues, and promote enterprises to follow the investment direction of the country. Then, in view of Beijing's cultural and creative enterprises, the following hypothesis is proposed:

H4c: Board political connectedness is positively related to FDI performance

Duru \& Reeb (2002) and Denis et al. (2002) believe that in the overseas market, companies will face cultural and legal differences in different countries, which urge shareholders and board members to spend more efforts to master the company's overseas operations. The directors could be the source of globalization and professional knowledge, so as to better understand and cope with the overseas institutional pressure, influence the local government, and enhance the legitimacy of enterprises in the external environment. As for the FDI of cultural and creative enterprises, the international influence ability of cultural products and brand directly affects and restricts the effect of the implementation of the strategy of enterprise internationalization. So, in view of Beijing's cultural and creative enterprises, the following assumptions are put forward:

H4d: The internationalization of board is positively related to FDI performance 


\section{Research Methods}

\subsection{Data and sample}

This paper selects the listed companies of culture, media and communication in Beijing as the research sample selection range, selects the companies that have carried out FDI projects, and extracts the relevant data of FDI projects. Finally, 14 companies were selected as the analysis objects, including 7 A-share enterprises in Shenzhen Stock Exchange, 3 A-share enterprises in Shanghai Stock Exchange, 3 listed companies in Hong Kong stock exchange, and 1 listed enterprise in New York Stock Exchange of the United States. A total of 128 project sample data were obtained. The data sources used are the company annual report information published on the appropriate stock exchange, as well as wind database data, cultural dimension data published by Hofustde website, voyage information on air travel website, etc.

\subsection{Variables and Model}

\subsubsection{Variables}

This study explores the influence of cultural distance, geographical distance and board capital elements on FDI performance. Therefore, FDI performance is a dependent variable, while cultural distance, geographical distance and board capital element are independent variables (see Table 5-1). The distance dimension selects cultural distance (Dc) and geographical distance (Dg) as the measurement indicators. The board capital dimension is divided into two aspects: human capital and social capital of the board. The human capital of the board selects the age $(\mathrm{Ba})$, gender diversity $(\mathrm{Bg})$, education level $(\mathrm{Be})$ and cultural background width (Bp), the scale (Bs), interlocking (B1), political relevance $(\mathrm{Bn})$ and internationalization (Bi) are selected as indicators of social capital of the board.

From the scatter diagram of cultural distance and geographical distance, it can be observed that there is a strong correlation between cultural distance and geographical distance. The farther the geographical distance is, the greater the cultural distance is (see Fig.1). Therefore, the interaction between cultural distance and geographical distance should be considered in the model. Hence, this paper introduces the product term of cultural distance and geographical distance $(\mathrm{Dc} * \mathrm{Dg})$ as the control variable.

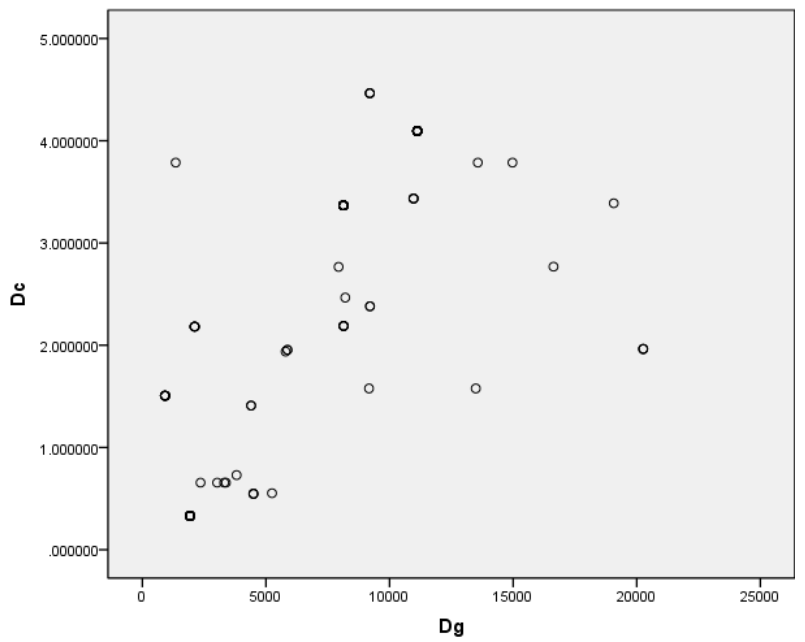

Figure 1. scatter diagram of cultural distance and geographical distance

TABLE I. Variable Symbol, Definition and Measurement

\begin{tabular}{|c|c|c|c|}
\hline & name & Symbol & Definition and measurement of variables \\
\hline $\begin{array}{l}\text { Dependent } \\
\text { variable }\end{array}$ & FDI Performance & $\mathrm{P}$ & $\begin{array}{l}\text { As of } 2018 \text {, the operation results of FDI projects: the value of exit operation } \\
\text { is } 1 \text {, the value of equity reduction is } 2 \text {, the value of equity unchanged is } 3 \text {, } \\
\text { and the value of equity increase is } 4\end{array}$ \\
\hline \multirow[t]{8}{*}{$\begin{array}{l}\text { Independent } \\
\text { variable }\end{array}$} & Cultural distance & Dc & According to Kogut $\&$ Singh (1988) formula $C D_{i j}=\frac{1}{6} \sum_{n=1}^{6} \frac{\left(I_{n i}-I_{n j}\right)^{2}}{V_{n}}$ \\
\hline & Geographical distance & $\mathrm{Dg}$ & $\begin{array}{l}\text { Route distance from Beijing to capitals of other countries or from Beijing to } \\
\text { Hong Kong. }\end{array}$ \\
\hline & Board age & $\mathrm{Ba}$ & The average age of directors of the board of directors in the year of FDI. \\
\hline & Board gender diversity & $\mathrm{Bg}$ & The total number of women on the board of directors in the year of FDI. \\
\hline & Board education level & $\mathrm{Be}$ & $\begin{array}{l}\text { The average educational background of directors of the board in the year of } \\
\text { FDI: } 4 \text { points for doctoral degree, } 3 \text { points for master's degree, } 2 \text { points for } \\
\text { bachelor's degree and } 1 \text { point for college degree. Each director only records } \\
\text { the highest score, and the final total score is divided by the number of } \\
\text { people. }\end{array}$ \\
\hline & $\begin{array}{l}\text { Board culture } \\
\text { background width }\end{array}$ & $\mathrm{Bp}$ & $\begin{array}{l}\text { Overseas directors (including Hong Kong, Macao and Taiwan) have } 3 \text { points, } \\
2 \text { points have overseas study or work experience, and } 1 \text { point work } \\
\text { experience in domestic and foreign enterprises and foreign institutions. Each } \\
\text { director only records the highest score, and the final total score is divided by } \\
\text { the number of people. }\end{array}$ \\
\hline & Board size & Bs & The total number of directors of FDI in that year. \\
\hline & Board interlocking & $\mathrm{B} 1$ & $\begin{array}{l}\text { In the year of FDI, the number of directors serving in other enterprises at the } \\
\text { same time, each appointment takes } 1 \text { point, and the total score is obtained by } \\
\text { summing up. }\end{array}$ \\
\hline
\end{tabular}




\begin{tabular}{l|l|l|l}
\hline & $\begin{array}{l}\text { Political relevance of the } \\
\text { board }\end{array}$ & $\begin{array}{l}\text { In the year of FDI, the number of directors serving in domestic government } \\
\text { agencies, industry associations, etc.,each appointment takes 1 point, and the } \\
\text { final total score is divided by the number of directors. }\end{array}$ \\
\hline $\begin{array}{l}\text { Internationalization of } \\
\text { board }\end{array}$ & $\begin{array}{l}\text { In the year of FDI, the number of directors holding posts in overseas } \\
\text { institutions, etc., each appointment takes 1 point, the final total score is } \\
\text { divided by the number of directors. }\end{array}$ \\
\hline $\begin{array}{l}\text { Control } \\
\text { variable }\end{array}$ & $\begin{array}{l}\text { Cross term of cultural } \\
\text { distance and } \\
\text { geographical distance }\end{array}$ & Cultural distance x geographical distance \\
\hline
\end{tabular}

\subsubsection{Model}

According to the above analysis, the paper establishes a data model to study the influence of cultural distance, geographical distance and board capital on the FDI performance of cultural and creative enterprises in Beijing, and uses multiple logistic regression analysis to test the research hypothesis. The basic form of the equation is as follows.

$$
\begin{aligned}
& \operatorname{Logit}\left(P_{1}\right)=\ln \left[\frac{P_{1}}{P_{1}}\right]=0 \\
& \operatorname{Logit}\left(P_{2}\right)=\ln \left[\frac{P(Y=2 \mid X)}{P(Y=1 \mid X)}\right]=\alpha_{2}+\beta_{101} D c+\beta_{102} D g+\beta_{103} B a+\beta_{104} B g \\
& +\beta_{105} B e+\beta_{106} B p+\beta_{107} B s+\beta_{100} B 1+\beta_{1009} B n+\beta_{110} B i+\beta_{111} D c^{*} D g
\end{aligned}
$$

$$
\begin{aligned}
& \operatorname{Logit}\left(P_{3}\right)=\ln \left[\frac{P(Y=3 \mid X)}{P(Y=1 \mid X)}\right]=\alpha_{3}+\beta_{201} D c+\beta_{202} D g+\beta_{203} B a+\beta_{204} B g \\
& +\beta_{205} B e+\beta_{206} B p+\beta_{207} B s+\beta_{208} B 1+\beta_{209} B n+\beta_{210} B i+\beta_{211} D c * D g
\end{aligned}
$$

$$
\begin{aligned}
& \operatorname{Logit}\left(P_{4}\right)=\ln \left[\frac{P(Y=4 \mid X)}{P(Y=1 \mid X)}\right]=\alpha_{4}+\beta_{301} D c+\beta_{302} D g+\beta_{303} B a+\beta_{304} B g \\
& +\beta_{305} B e+\beta_{306} B p+\beta_{307} B s+\beta_{300} B 1+\beta_{309} B n+\beta_{310} B i+\beta_{311} D c^{*} D g
\end{aligned}
$$

Among them, $\alpha_{2-4}$ are intercept, $\beta 101-311$ are coefficient.

\subsection{Regression Analysis}

\subsubsection{Descriptive Statistics of Variables}

According to the statistical results in table 2, the standard deviation of Dc is 1.461 , which indicates that there are significant differences in cultural distance among different samples. Geographic distance variable differences on each sample, Dg minimum value of 914, a maximum of 20260. The minimum value of $\mathrm{Bg}$ is 0 , and the maximum value is 4 , which indicates that there are significant differences in the number of female directors among different samples. The minimum value of BP is 0 , which indicates that there is a lack of cross-cultural background in the board of some enterprises. The minimum value of $B s$ is 2 and the maximum value is 13 , which indicates that the number of directors in different projects is significantly different. The minimum value of $\mathrm{Bi}$ is 0 , the maximum value is 39 , and the average value is 0.352 , which indicates that the number of directors serving overseas is relatively small. In the Spearman

\begin{tabular}{|c|c|c|c|c|c|}
\hline $\begin{array}{c}\text { Variable } \\
\text { name }\end{array}$ & Observation sample & minimum value & Maximum value & mean value & standard deviation \\
\hline Dc & 128 & 0.331 & 4.465 & 2.451 & 1.461 \\
\hline $\mathrm{Dg}$ & 128 & 914 & 20260 & 7183.195 & 4608.530 \\
\hline $\mathrm{Ba}$ & 128 & 41 & 62 & 51.838 & 4.417 \\
\hline $\mathrm{Bg}$ & 128 & 0 & 4 & 1.438 & 1.222 \\
\hline $\mathrm{Be}$ & 128 & 1.778 & 3.571 & 2.796 & 0.404 \\
\hline $\mathrm{Bp}$ & 128 & 0 & 2.5 & 0.832 & 0.508 \\
\hline Bs & 128 & 2 & 13 & 8.477 & 1.716 \\
\hline $\mathrm{Bl}$ & 128 & 0 & 39 & 9.242 & 8.709 \\
\hline $\mathrm{Bn}$ & 128 & 0 & 3 & 0.645 & 0.710 \\
\hline $\mathrm{Bi}$ & 128 & 0 & 3 & 0.352 & 0.664 \\
\hline
\end{tabular}
correlation coefficient test between variables, except DC and DG independent variable correlation coefficient is 0.801 , and $\mathrm{B} 1$ and $\mathrm{Bi}$ independent variable correlation coefficient is 0.752 , other independent variables correlation coefficient is small (see table 3 ).

TABLE II. descriptive statistics of variables 
TABLE III. Spearman Correlation Coefficient among Variables

\begin{tabular}{|c|c|c|c|c|c|c|c|c|c|c|}
\hline & $\mathrm{P}$ & $\mathrm{Dc}$ & $\mathrm{Dg}$ & $\mathrm{Ba}$ & $\mathrm{Bg}$ & $\mathrm{Be}$ & $\mathrm{Bp}$ & Bs & $\mathrm{Bl}$ & $\mathrm{Bn}$ \\
\hline Dc & -0.101 & & & & & & & & & \\
\hline Dg & -0.137 & $\begin{array}{c}0.801 \\
* * *\end{array}$ & & & & & & & & \\
\hline $\mathrm{Ba}$ & $\begin{array}{c}-0.267 \\
* * *\end{array}$ & -0.092 & 0.091 & & & & & & & \\
\hline $\mathrm{P}_{0}$ & $\begin{array}{c}-0.165 \\
*\end{array}$ & 0.132 & 0.053 & $\begin{array}{c}-0.308 \\
* * *\end{array}$ & & & & & & \\
\hline $\mathrm{Be}$ & $\begin{array}{c}0.334 \\
* * *\end{array}$ & $\begin{array}{c}-0.196 \\
* *\end{array}$ & $\begin{array}{c}-0.155 \\
*\end{array}$ & $\begin{array}{c}-0.308 \\
* * *\end{array}$ & $\begin{array}{c}-0.254 \\
* * *\end{array}$ & & & & & \\
\hline $\mathrm{Bp}$ & $\begin{array}{c}-0.208 \\
* *\end{array}$ & -0.090 & 0.001 & $\begin{array}{c}0.490 \\
* * *\end{array}$ & $\begin{array}{c}-0.269 \\
* * *\end{array}$ & -0.059 & & & & \\
\hline Bs & 0.048 & 0.102 & 0.122 & 0.101 & 0.121 & 0.041 & -0.054 & & & \\
\hline $\mathrm{Bl}$ & 0.139 & $\begin{array}{c}-0.240 \\
* * *\end{array}$ & $\begin{array}{c}-0.257 \\
* * *\end{array}$ & 0.052 & $\begin{array}{c}-0.599 \\
* * *\end{array}$ & $\begin{array}{c}0.217 \\
* *\end{array}$ & $\begin{array}{c}0.197 \\
* *\end{array}$ & $\begin{array}{c}-0.380 \\
* * *\end{array}$ & & \\
\hline $\mathrm{Bn}$ & 0.015 & $\begin{array}{c}-0.291 \\
* * *\end{array}$ & $\begin{array}{c}-0.148 \\
*\end{array}$ & $\begin{array}{c}0.468 \\
* * *\end{array}$ & $\begin{array}{c}-0.518 \\
* * *\end{array}$ & $\begin{array}{c}0.201 \\
* *\end{array}$ & $\begin{array}{c}0.646 \\
* * *\end{array}$ & $\begin{array}{c}-0.412 \\
* * *\end{array}$ & $\begin{array}{c}0.528 \\
* * *\end{array}$ & \\
\hline $\mathrm{Bi}$ & 0.052 & $\begin{array}{c}-0.241 \\
* * *\end{array}$ & $\begin{array}{c}-0.258 \\
* * *\end{array}$ & 0.047 & $\begin{array}{c}-0.529 \\
* * *\end{array}$ & 0.143 & 0.120 & $\begin{array}{c}-0.508 \\
* * *\end{array}$ & $\begin{array}{c}0.752 \\
* * *\end{array}$ & $\begin{array}{c}0.471 \\
* * *\end{array}$ \\
\hline
\end{tabular}

Note: $* * *$, and $* *$ represent significance levels of $10 \%, 5 \%$ and $1 \%$, respectively (double tailed test)

\subsubsection{Multivariate Logistic Regression Results Statistics}

According to the above model, we use spss19.0 statistical software to obtain the analysis results of distance factor, board capital factor and FDI performance through multiple logistic regression to test the research hypothesis. In the process of step-by-step analysis, the first variables introduced are cultural distance and board capital elements, then the variable geographical distance is introduced, and finally the cross term of cultural distance and geographical distance is introduced. Model 1-1, model 1-2 and model 1-3 were obtained after analysis. In the regression test, the variance expansion factor VIF of all independent variables are less than 5, which means that it has passed the multicollinearity test; in model 1-3, the effect of equation likelihood ratio test at $1 \%$ level is significant, that means the results of model 1-3 have explanatory significance. The results show that, compared with model 1-1 and model 1-2, the relationship between explanatory variables and explained variables in model 1-3 is more significant. The results of model 1-3 showed that Dc, Dg, Bp were significantly negatively correlated with $\mathrm{P}$; $\mathrm{Bg}, \mathrm{Bs}, \mathrm{Be}, \mathrm{Bi}$ were significantly positively correlated with $\mathrm{P} ; \mathrm{Ba}, \mathrm{B} 1$ and $\mathrm{Bn}$ had no significant effect on $\mathrm{P}$ (see table 4).

TABLE IV. Multiple Logistic Regression Results

\begin{tabular}{c|c|c|c|c|c|c|c|c|c}
\hline \multirow{2}{*}{$\begin{array}{c}\text { Variable } \\
\text { name }\end{array}$} & \multicolumn{3}{|c|}{ Model 1-1 } & \multicolumn{3}{c|}{ Model 1-2 } & \multicolumn{3}{c}{ Model 1-3 } \\
\cline { 2 - 10 } Intercept & -1.33 & 7.54 & 14.65 & 6.82 & 14.85 & 21.98 & $\begin{array}{c}5478.75 \\
* *\end{array}$ & $\begin{array}{c}5487.14 \\
* *\end{array}$ & $\begin{array}{c}5495.35 \\
* *\end{array}$ \\
\hline $\mathrm{Dc}$ & -1.47 & $\begin{array}{c}-1.73 \\
*\end{array}$ & $\begin{array}{c}-1.73 \\
*\end{array}$ & -1.58 & -1.72 & -1.78 & $\begin{array}{c}-2176.31 \\
* *\end{array}$ & $\begin{array}{c}-2175.44 \\
* *\end{array}$ & $\begin{array}{c}-2176.45 \\
* *\end{array}$ \\
\hline $\mathrm{Dg}$ & & & & 0.00 & 0.00 & 0.00 & $\begin{array}{c}-0.62 \\
* *\end{array}$ & $\begin{array}{c}-0.62 \\
* *\end{array}$ & $\begin{array}{c}-0.62 \\
* *\end{array}$ \\
\hline $\mathrm{Ba}$ & 0.38 & 0.01 & -0.04 & 0.34 & -0.01 & -0.06 & -4.97 & -5.32 & -5.39 \\
\hline $\mathrm{Bg}$ & 1.82 & 0.12 & 0.19 & 2.22 & 0.52 & 0.61 & $\begin{array}{c}236.47 \\
*\end{array}$ & $\begin{array}{c}234.76 \\
*\end{array}$ & $\begin{array}{c}234.81 \\
*\end{array}$ \\
\hline
\end{tabular}




\begin{tabular}{|c|c|c|c|c|c|c|c|c|c|}
\hline $\mathrm{Be}$ & 2.43 & 1.44 & 2.29 & 1.46 & 0.44 & 1.41 & $\begin{array}{c}848.34 \\
* *\end{array}$ & $\begin{array}{c}846.40 \\
* *\end{array}$ & $\begin{array}{c}848.10 \\
* *\end{array}$ \\
\hline $\mathrm{Bp}$ & -7.37 & -5.28 & -7.72 & -10.93 & -8.84 & $\begin{array}{c}-11.23 \\
*\end{array}$ & $\begin{array}{c}-3374.22 \\
* *\end{array}$ & $\begin{array}{c}-3372.22 \\
* *\end{array}$ & $\begin{array}{c}-3374.52 \\
* *\end{array}$ \\
\hline Bs & -1.69 & -.09 & -.41 & -1.29 & 0.34 & -0.01 & $\begin{array}{c}268.59 \\
* *\end{array}$ & $\begin{array}{c}270.25 \\
* *\end{array}$ & $\begin{array}{c}269.87 \\
* *\end{array}$ \\
\hline $\mathrm{Bl}$ & 0.28 & 0.14 & 0.16 & 0.24 & 0.10 & 0.12 & -8.40 & -8.53 & -8.53 \\
\hline $\mathrm{Bn}$ & -4.88 & -1.34 & -3.64 & -5.23 & -1.66 & -4.08 & -8.06 & -3.90 & -6.81 \\
\hline $\mathrm{Bi}$ & 3.43 & 2.70 & $\begin{array}{c}4.84 \\
*\end{array}$ & 8.70 & 7.92 & 10.08 & $\begin{array}{l}4005.80 \\
* *\end{array}$ & $\begin{array}{c}4004.72 \\
* *\end{array}$ & $\begin{array}{c}4007.20 \\
* *\end{array}$ \\
\hline $\mathrm{Dc}^{*} \mathrm{Dg}$ & & & & & & & $\begin{array}{c}0.18 \\
* *\end{array}$ & $\begin{array}{c}0.18 \\
* *\end{array}$ & $\begin{array}{c}0.18 \\
* *\end{array}$ \\
\hline $\begin{array}{l}\text { Likelihood } \\
\text { ratio test }\end{array}$ & & $0.000 * *$ & & & $0.000 * *$ & & & $0.000 * *$ & \\
\hline
\end{tabular}

Note: The reference category is $1,{ }^{*}$ and $* *$ represent significance levels of $5 \%$ and $1 \%$, respectively (double tailed test)

\subsubsection{Discussion of Multiple Logistic Regression Results}

Except H3a, H3d, H4b, H4c not verified, other hypotheses were verified and Control variable's affection was significant (see table 5). Of all the hypotheses, only the $\mathrm{H} 3 \mathrm{~d}$ analysis result was inconsistent with the correlation in the original hypothesis content. This indicates that the current measurement of the cultural width of the board may not be completely consistent with the actual location of FDI, so the expected impact effect has not been measured. The other three hypotheses that have not been verified are only insufficient in significance, but still have a certain effect, which need further research and analysis in the future.

From H1, H2, H3b, H3c, H4a, H4d these verified hypotheses can be known, cultural distance, geographical distance, gender diversity, education level, director number and board internationalization have a significant influence on the FDI of cultural and creative enterprises, and enterprises need to strictly control these factors. Cultural and creative enterprises should carefully consider the cultural and geographical factors when conducting FDI. When the cultural and geographical distance is large, comprehensive measures should be taken to reduce the negative impact.

TABLE V. The Empirical Analysis Results

\begin{tabular}{|c|c|c|}
\hline & The content of Hypothesis & Verification result \\
\hline H1 & Cultural distance is negatively related to FDI performance & verified \\
\hline $\mathrm{H} 2$ & $\begin{array}{l}\text { Geographical distance is negatively related with FDI } \\
\text { performance }\end{array}$ & verified \\
\hline $\mathrm{H} 3 \mathrm{a}$ & Board age is positively related with FDI performance & not verified \\
\hline $\mathrm{H} 3 \mathrm{~b}$ & $\begin{array}{l}\text { Board gender diversity is positively related with FDI } \\
\text { performance }\end{array}$ & verified \\
\hline $\mathrm{H} 3 \mathrm{c}$ & $\begin{array}{c}\text { Board education level is positively related with FDI } \\
\text { performance }\end{array}$ & verified \\
\hline $\mathrm{H} 3 \mathrm{~d}$ & $\begin{array}{l}\text { The width of directors' cultural background is positively } \\
\text { related to FDI performance }\end{array}$ & not verified \\
\hline $\mathrm{H} 4 \mathrm{a}$ & Board size is positively related with FDI performance & verified \\
\hline $\mathrm{H} 4 \mathrm{~b}$ & $\begin{array}{l}\text { Board interlocking is positively related with FDI } \\
\text { performance }\end{array}$ & not verified \\
\hline $\mathrm{H} 4 \mathrm{c}$ & $\begin{array}{l}\text { Board political connectedness is positively related to FDI } \\
\text { performance }\end{array}$ & not verified \\
\hline $\mathrm{H} 4 \mathrm{~d}$ & $\begin{array}{l}\text { The internationalization of board is positively related with } \\
\text { FDI performance }\end{array}$ & verified \\
\hline
\end{tabular}




\section{Conclusions and Suggestions}

\subsection{Conclusions}

The empirical conclusion is: cultural distance and geographical distance are negatively correlated with FDI performance; gender diversity, education level, scale and internationalization of board are significantly positively correlated with FDI performance. Geographical distance, institutional rules, political risks and cultural conflicts will lead to difficulties in varying degrees, and even lead to great setbacks and failed investment. The board is a bridge between the company and the external environment, and it is a mechanism to manage external variables and reduce environmental uncertainty. Therefore, how to make the board play a role of decision-making for rational allocation of resources and coping with risk of enterprise internationalization is an important realistic problem in the process of FDI of China enterprises.

\subsection{Suggestions}

In the process of FDI, enterprises must be fully aware of business barriers and risks. As enterprises in developing countries, there is a big gap in strength and experience compared with multinational companies in developed countries. Enterprises should be sufficient aware of the negative effects of cultural distance, geographical distance and institutional distance, especially the recessive and long-term effects of cultural distance. The board is the strategic decision-making body of an enterprise, and FDI action ia started from it. Hence, enterprises should constantly strengthen the construction of the board system and build a strong capital structure of the board, so as to conform to the FDI strategy and mode of enterprises. While building human capital and social capital, the board should also build an international management team to meet the needs of more FDI actions and support the strategic decisions of the board of directors. Finally, enterprises should establish a special coordination agency in the process of FDI. Enterprises can take the board structure as the leader, extend to the management organization of overseas enterprises, thereby establishing a special coordination structure.

\section{Acknowledgments}

Supported by: The project in the fund of Beijing Social Science of China (No.14JGB028); The construction program of innovation team at Beijing Institute of Fashion Technology (BIFTTD201901); The project of the education \& teaching reform at Beijing Institute of Fashion Technology (No. ZDJG1807).

\section{References}

1. Olie R.. (1994) Shades of culture and institutions in international mergers $[\mathrm{J}]$. Organization Studies,
15(3): 381-405

2. Kirkman B. L., Lowe K. B. \& Gibson C. B.. (2006) A quarter century of culture's consequences: A review of empirical research incorporating Hofstede's cultural values framework [J]. Journal of International Business Studies, 37(3): 285-320

3. Kwok L., Bhagat R. S., Buchan N. R., Erez M. \& Gibson C. B.. (2005) Culture and international business: Recent advances and their implications for future research $[\mathrm{J}]$. Journal of International Business Studies, 36(4): 357-378

4. Adler N. J.. (2002) International dimensions of organizational behaviour (4th ed.) [M]. Cincinnati, $\mathrm{OH}$ : South-Western

5. Luostarinen R.. (1980) Internationalization of the Firm [M]. Helsinki:The Helsinki School of Economics

6. Hofstede G.. (1980) Culture's consequences: International differences in work-related values [M]. London: Sage Publications 